\title{
Dynamic Mathematical Models Applied to Competitiveness Management of Modern Russian University
}

\author{
Alexander Losev \\ Volgograd State University, \\ Institute of mathematics and informational technologies \\ Volgograd, Russia \\ alexander.losev@volsu.ru
}

\author{
Natalia Loseva \\ Volgograd State University, \\ Volzhsky Institute of humane studies (branch), \\ Volgograd region, Russia \\ loseva_nat@vgi.volsu.ru
}

\author{
Vasiliy Tarakanov \\ Volgograd State University, \\ Volgograd, Russia \\ rector@volsu.ru
}

\begin{abstract}
The article is concerned with the methodology of funding of structural university units and project groups, which is aimed at achieving the main performance targets of the higher educational institution effectiveness, as well as at the strategic development programs, including those focused on sustainable and competitive development of the region. The particular methodology is based on a dynamic mathematical model developed in accordance with the principles of normative per capita financing of higher education, the structure of educational curricula, administrative documents of the Government of the Russian Federation, the Strategy for Social and Economic Development of the Region, and relevant statistical data. The implementation of this model allows to create conditions for the financial provision of the basic projects of development programs of the educational institution, such as the "roadmap" or plan of actions of the project "Universities as centers of innovation spaces". The latter, in turn, is the most important requirement for the sustainable and competitive development of the regional economy. The particular model is a natural evolution of the method of normative per capita financing within the state order and represents a significant step forward in the context of the development of a modern system of financial management at the universities.
\end{abstract}

Keywords: financial management, effectiveness targets of university, amount of funding, mathematical model

\section{INTRODUCTION}

In recent years, "smart specialization" has been increasingly recognized throughout the world. Initially, this concept was formulated by the European Commission's group "Knowledge for Growth" as the main strategy for innovative development of the regions. This term also refers to a regional strategy of the innovation management, which establishes priorities aimed at obtaining competitive advantages by developing its own scientific and innovative potential (European Commission, 2014).

A number of experts (see f. ex. [1]) note that "the competitiveness caused by innovation is a critical condition for long-term (i.e. sustainable) economic development in the modern global knowledge economy." Obviously, the competitiveness of national economies in general, and regional economies in particular, is determined by a number of factors. The World Economic Forum identifies 12 such parameters.

An important role among them plays the factor No. 5 "Higher Education and training". According to the Global Competitiveness Report 2017-2018 delivered by World Economic Forum, Russia rose by 5 lines compared to last year and took the 38th place among 137 countries in the ranking. As the main growth driver acts a significant improvement in the macroeconomic situation. Additional factors that allowed Russia to rise in this competitiveness rating were the acceleration of the digitalization of the economy, as well as the increase of the community participation in higher education and the increase in the assessment of quality by education managers.

Understanding that higher education is an integral part of the country's competitive advantages leads to a meaningful change by the renewal of the higher education system. As it is mentioned in the article [2], "at the first stages of the reforms it was supposed to improve the quality of education by resources concentration in the most competitive universities. As a result of this policy, there has been a significant 
reduction in regional powers in the field of education and the expansion of federal ones. The latter has given rise to a number of negative aspects. In particular, as noted in [3], "the center ceases to cope with its powers, offers standard solutions where their implementation has a negative effect."

The current priority project "Universities as centers of innovation space" refines the progress of reforms in the sense of promoting the logic of regional development in determining the effectiveness of the Russian education system (see [2]). Moreover, as noted by a number of experts (see, for example, [4]), under these conditions "the need for tools and methods, that allow to manage in an efficient manner various aspects of the university's activities, becomes obvious ". In this respect, we would like to mention an interesting fact, revealed at the Tomsk Polytechnic University within the research on the topic of "Methodology for the search for competitive advantages of the university: problems, experience, prospects" (see [4]). It follows that one of the least developed management elements in the university (the 7 th place out of 8 ) according to the academic environment is a strategic financial management. Most likely, a similar situation will be observed in most other universities in Russia.

The tasks for modernization of the management system of universities, including the main provisions of strategic financial management, in recent years have acquired special relevance and have become the subject of research by many Russian scientists. "Classical ways to manage universities in the market economy environment found themselves as untenable. With the inclusion of the education system in the Bologna process, the management challenges confronting the university, which previously were solved by ministries and departments, should now be addressed directly to the university. This situation means a high level of responsibility of the executive management of the university for the results of its activities, and requires well-founded decisions making" [5]. O. Rudakova also takes a favorable view of the transition to a new management system of the university. "Evaluation of the ongoing modernization in the management of educational processes of higher professional education confirms that many problems of education, including competitiveness, can not be successfully solved within the framework of the current concept of market management in the sphere of educational services. Ever more topical is the transition to a new management system, which assumes creation of a qualitatively different competitive position of universities in the market [6]. The need to introduce new financial management algorithms is mentioned in the work [7]: "... with the help of modern instruments of financing and the application of new models for managing the financial flows of a university, we can influence their competitiveness".

As for the transformation of the management system, a preliminary development of appropriate techniques, algorithms and technologies are expected. This task is relevant for all Russian universities. Including for the purposes of solving the particular problem, on the basis of the Order No. 347 dated 14.04.2017 the Ministry of Education and Science established a working group on methodological support for improving the organizational structure of educational institutions of higher education and increasing the efficiency of labor remuneration for employees of higher educational institutions.

This article is devoted to one of the aspects of improving the system of strategic financial management. It is important for the university's management team to address challenges concerning an effective management of the organization, using at least medium-term planning. Exactly this way it is possible to identify "bottleneck", to make more adequate and optimal management decisions, aimed primarily at solving the problems of sustainable and competitive development of the region's economy, as well as settlement of other internal and external problems facing the university.

The main goal of the research is to create a dynamic financial and mathematical model that allows to gain the target performance indicators of the university, as the center of innovation, technological and social development of the region.

\section{MATERIALS AND Methods (MODEL)}

The change in the funding system of universities, which began in 2012 with the introduction of a normative per capita system, gave impetus to the creation of fundamentally new methods of economic analysis and financial management algorithms for the university as a whole and its structural units in particular.

According to the documents of the Ministry of Education and Science of the Russian Federation, the components of the standard costs include: costs of faculty labor remuneration; the costs of acquiring inventories; costs for the acquisition of educational literature, periodicals, publishing services; the costs of organizing practical training and manufacturing practice; expenses for public utilities; the cost of maintaining the property; payment for communication services; costs for transport services; the costs of upgrading the qualifications of the teaching staff; costs for the periodic medical examination of the faculty; labor expense of employees of the educational organization that do not directly participate in the provision of public services (executive and administrative personnel, educational support staff, housekeeping staff); expenses for purchase of fixed assets; the cost of organizing cultural, mass, physical and health activities for students.

It seems as if some significant activities of the educational organization, for example, scientific research, are not clearly spelled out in the documents regulating the normative per capita financing of the state order. But, on the other hand, educational standards provide for possible very serious scientific research. Moreover, the effectiveness monitoring of educational institutions of higher education is based on 16 items within the list of scientific and research indicators. One of the most important indicators of the operational effeciency of the university is "The ratio of the salaries of the faculty to the average wage in regards to the economy of the region". There are also indicators of educational, international, financial and economic activities, performance targets of the projects within the university development program (for example, plan of actions or the roadmap of the project "Universities as centers of innovation spaces") and others. Obviously, the issue of creating financial management 
algorithms that would take into account the fulfillment of performance targets of universities is getting more topical.

It can be observed that in the papers [8] - [10] a financialmathematical model of budgeting of structural organization units of higher educational institutions was developed on the basis of curriculum and financial plans of educational programs and methodology of normative per capita financing of educational organizations' activities in the implementation of the state order. In particular, in the study [10] a model of financing of educational and research structural units has been developed, the ultimate goal of which is to achieve the basic targets of the university's performance efficiency. Fully justified, that implementation of this method leads to improved efficacy of research and teaching process organization, formation of financial mechanism for implementing long-term research academic programs. However, the model is static, which is its main drawback in practical implementation.

The present article is concerned with the development of a dynamic mathematical model, which implementation will make possible to achieve a number of performance targets within the framework of the university functioning, including a "roadmap" of changes in social sectors aimed at improving the efficiency of education and science in general. In particular, the fulfillment of the following planned figures is ensured: the ratio of the faculty average salary of the higher educational institution to the average wage in the region; the ratio of teaching staff rates to the number of students, etc.

Let us introduce some input values of the model. Suppose $u(t)$ is a planned figure of the number of students (reduced enrollment) per 1 teaching staff rate; $Z P_{\text {REG }}(t)$ equals an estimated figure of the average wage in the particular region; $c(t)$ - a target of ratio of the average salary of the university's faculty to the average wage in the region; $Q_{s}(t)$ is a projected value of the funding of science at the university received from external sources (grants, etc.), as well as other similar projects refered to the salaries of the teaching staff; $Q_{p r}(t)$ is a projected value of amount of financing in order to award a bonus to the faculty at the expense of extra-budgetary sources.

In this particular case the variable $t$ denotes the planning time. Taking into account the peculiarities of this subject area, including the times of the beginning and the end of the academic and calendar years, it is proposed to divide the calendar year into two parts: the first - from 01.01 to 31.08 (we will refer to it first "half a year"), and the second - from 01.09 to 31.12 (second "half a year"). Let us suppose that the planning process begins with a new calendar year. Then, for the first planning period, it is convenient to put $t=2 k$, where $k$ stands for the current planning year, and $t=2 k+1$ for the second planning period of the current year.

A noteworthly detail is that in the described below list of figures, a part of them is determined by the relevant decisions of the government of the Russian Federation, the other is of a prognostic nature, but it can fully faithful be determined on the basis of information available at universities and strategic development plans.
Next, let $K(i, j, t)$ denote a number of students (student body), studying in $\mathrm{j}$-th year of the $\mathrm{i}$-th educational program (academic program), with the variable $i$ we will assign values in accordance with the classifier in the planning period $t$. Let us designate the number of students attending the eveningtime courses (extramural form of study) as $K V(i, j, t)$, the number of extra-mural students as $K Z(i, j, t)$ and a prospective students recruitment for the first year of studies upon any educational program as $-\mathbb{K}(i, 1, t)$. As we can see, the students contingent of each course year is not a constant. Therefore, having studied its dynamics over the previous several years, we can introduce the coefficient of variation of the students' contingent $s(i, j, t)$. Then within the framework of the model, the following approximations can be used

$$
K(i, j, 2 k)=K(i, j, 2 k-1) \cdot \delta(i, j, 2 k)
$$

and

$$
K(i, j, 2 k+1)=K(i, j-1,2 k) \cdot \delta(i, j-1,2 k+1)
$$

Similar formulas are valid for other forms of education. Thus, the students contingent of the university for the planning period $t$ can be calculated from the formula

$$
\begin{gathered}
K(t)=\sum_{i=1}^{N} \sum_{j=1}^{b}(K(i, j, t-1)+K V(i, j, t-1)+ \\
+K Z(i, j, t-1))
\end{gathered}
$$

where $N$ equals the number of educational programs of the university, $b$ is the maximum number of courses on specialties and training directions. According to the corresponding formulas, the so-called reduced students contingent of the university $\mathbb{K}_{\text {FNIV }}(t)$ for the planning period $t$ is calculated.

Further, using the values of the input parameters of the model for the planning period $\boldsymbol{t}$, we can determine the values of the dependent variables of the model.

Then, in accordance with the targets, the amount of university rates of teaching staff in the period $t$ can be computed by the prime relation :

$$
S T(t)=\frac{K_{F N N}(t)}{u(t)}
$$

Thus, the amount of financing needed to achieve the target ratio of the average salary of the university's faculty and the regional average during the planning period should be calculated by the formula

$$
Q(t)=5 T(t) \cdot Z P_{R E G}(t) \cdot c(t)
$$

Therefore, the amount of financial support that is to be directed to cover the costs for remuneration of labor of the 
faculty at the expense of per capita financing can be determined by the following formula

$$
Q_{N F F}(t)=Q(t)-Q_{s}(t)-Q_{p r}(t)
$$

Suppose $q_{v \pi}(t)$ - equals an expected a year $(\mathrm{t})$ normative part of the funding for the educational program (per student), allocated by the university in the labor compensation fund of the faculty for academic work payment.

The result is that the total amount of funding directed by the university to support educational activities can be determined by the formula

$$
q_{v R}(t)=q_{v R}(t) \cdot K(t)
$$

The remaining amount of financing, which is calculated by the formula

$$
Q_{N R}(t)=Q_{N F F}(t)-Q_{V R}(t)
$$

can (and should) be transfered for the payment of salaries to the university faculty and staff who will ensure the implementation of various projects intended to strategic development of the university. This projects portfolio can include programs, which implementation will guarantee the settlement of questions concerning an innovative, technological and social development of the region, increase the competitiveness of the university and will serve as a driver for solving other required tasks.

\section{RESULTS AND DISCUSSION}

Thus, a dynamic mathematical model of the funding of educational, scientific research and other structural organizational units has been proposed above. The implementation of this model will contribute to the achievement of main targets of the efficient university management, as well as ensure quality improvement of university programs aimed at competitive and sustainable development of the regional economy. The developed financial and mathematical model allows to forecast the amounts of funding for educational, scientific and other kinds of university activity to fulfill the targets of the ratio of the average salary of faculty to the average wage in the region, as well as the targets of the volume of research work and development activities per academic. From our point of view it is possible to carry out the necessary calculations for the next year and for the future, that would contribute to optimizing the internal financial structure of the university and increasing its competitiveness.

The particular model can be applied to any university, its implementation will lead to the rise in the efficiency of the educational and research process organization, to the creation of a financial mechanism to carry out some long-term research programs. The next optional step in the development of this model is the creation of the formation methodology, budgets of structural divisions and design groups optimal for goalsetting. This methodology should be based on the multiobjective optimization and on a clear hierarchical system of goals of scientific and educational work (annual university goals, on their basis the goals of institutes and faculties, and further, departments, and project groups), as well as on a system of performance-based contracts of employment of the faculty. Therefore, each director of a structural university unit when allocating the payroll budget of a structural unit, which was determined in accordance with the developed methodology, will be guided by the approved goals of the structural unit and the criteria of performance-based contracts of employment for its staff (in addition to compulsory implementation of federal state educational standards and other requirements established by relevant external and local normative documents). The point to be emphasized is that the application of the described methodology stimulates the heads of structural university units to optimize the educational process, provided that the goals set for the structural unit and the criteria for the fulfilment of the performance-based contracts of employment are met by the head of the structural unit, because any optimization of the educational process does not lead to a reduction in the payroll budget of the structural unit.

We believe that this fact, among other things, will result in the formation of a financial resources reserve of the particular unit, that makes possible for its director to attract more skilled and highly paid teaching staff to hold certain courses, to build a system of performance-based contracts of employment within the chairs to achieve the targets set for the structural unit and to fulfill the provisions of an employment contract of the head of the structural unit personally.

\section{CONCLUSION}

The modern mechanisms of university management bring to the forefront the ability to form and allocate financial resources, assess the risks of implementing various solutions, and reasonably change the adopted plan of action. This affects the assessment of the effectiveness of the university, its role in ensuring a competitive and sustainable development of the region's economy, the employability of graduating students on the labor market. The dynamic model presented in the particular article allows to plan the funding of the university in the future, organize efficient and transparent spending of financial and human resources by the implementing the portfolio of innovative academic programs. In addition, its application will help to allocate the budget for the provision of educational and research work, provide a financial support for the performance-based employment contacts, forecast the fulfillment of target performance indicators of universities, and, as a result, increase the competitiveness of the educational institution.

\section{Acknowledgment}

The reported study was supported by Russian Foundation for Basic Research and Administration of the Volgograd region, project "Financial and mathematical models and algorithms for budgeting structural units of educational organizations ”, №17-12-34015. 


\section{References}

[1] E. Karayannis, E. Grigorudis, "Quadruple Innovation Helix and Smart Specialization: Knowledge Production and National Competitiveness" [Chetyrekhzvennaya spiral' innovatsii i "Umnaya spetsializatsiya": proizvodstvo znanii i natsional'naya konkurentosposobnost'], FORESIGHT [Forsait], 2016, Vol. 10, No 1, pp. 31- 42.

[2] M.V. Kurbatova, E.S. Kagan, "The Role of Universities in the Formation of Scientific and Technological Potential and in Development of Russian Federation Regions" [Rol' universitetov v formirovanii nauchnotekhnicheskogo potentsiala i razvitii regionov Rossiiskoi Federatsii], University Management: Practice and Analysis [Universitetskoe upravlenie: praktika i analiz], 2017, Vol. 21 (5), pp. 74 - 81.

[3] A.N. Maiorov, "Challenges and Risks of Centralization of Powers in Education Management" [Problemy i riski kontsentratsii polnomochii v sisteme upravleniya obrazovaniem], Educational Studies [Voprosy obrazovaniya], No. 3, pp. 274 - 287.

[4] A.S. Latyshev, Yu.P. Pokholkov, M.Yu. Chervach, A.N. Shadskaya, "Managing Competitiveness of Contemporary Russian University: Status, Challenges and Responses" [Upravlenie konkurentosposobnost'yu sovremennogo rossiiskogo universiteta: sostoyanie, vyzovy i otvety], University Management: Practice and Analysis [Universitetskoe upravlenie: praktika i analiz], 2017, Vol. 21 (5), pp. 6 - 16.

[5] N.P.Korzhavina, V.A.Leongardt, O.A.Chikova, "Competitiveness of Universities in the Market of Educational Services and the Labor Market: the Interrelation of Components and Indicators" [Konkurentosposobnost' vuzov na rynke obrazovatel'nykh uslug i rynke truda: vzaimosvyaz' komponentov i pokazatelei], Pedagogical Education in Russia
[Pedagogicheskoe obrazovanie v Rossii], 2016, no. 8, pp. 144-147.

[6] O.V.Rudakova, "Mechanisms of Increase in Competitiveness of the Russian Higher Education Institutions" [Mekhanizmy povysheniya konkurentosposobnosti rossiiskikh vuzov], Russian science and education today: problems and prospects [Rossiiskaya nauka i obrazovanie segodnya: problemy i perspektivy], 2015, no.1, pp. 27-29.

[7] V.Yu.Pashkus, "High school in the new economy: the modern financial competitiveness instruments" [Vuz v novoi ekonomike: sovremennye finansovye instrumenty obespecheniya konkurentosposobnosti], Journal Marketing MBA. Marketing management firms [Marketing MBA. Marketingovoe upravlenie predpriyatiem], 2016, vol.7- Issue 2, pp. 245264.

[8] S.A. Korolkov, A.G. Losev, I.M. Reshetnikova, V.V. Tarakanov, "Budgeting model of structural units based on normative per capita funding", European researcher, Series A, 2014, Vol. 70, no. 3-1, pp. 498-508.

[9] S.A. Korolkov, A.G. Losev, V.V. Tarakanov, "Education Programs Management by Education and Finance Plans Implementation" [Upravlenie obrazovatel'nymi programmami cherez vnedrenie uchebnofinansovykh planov], University Management: Practice and Analysis [Universitetskoe upravlenie: praktika i analiz], 2016, no. 4 (104), pp. $50-56$.

[10] S.A. Korolkov, A.G. Losev, V.V. Tarakanov, "Model of Financial Support for the Implementation of Target Indicators of Efficiency of the University" [Model' finansovogo obespecheniya vypolneniya tselevykh pokazatelei effektivnosti raboty vuza], University Management: Practice and Analysis [Universitetskoe upravlenie: praktika i analiz], 2017, Vol. 21, no.6, pp.49-57. 